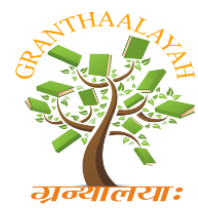

INTERNATIONAL JOURNAL OF RESEARCH GRANTHAALAYAH

A knowledge Repository

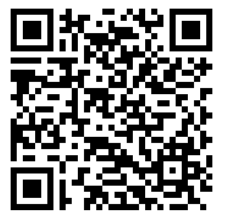

Science

\title{
EFFECTS OF SUBSTRATES, WEIGHT AND PHYSIOLOGICAL STAGE OF SUCKERS ON MASSIVE PROPAGATION OF PLANTAIN (MUSA PARADISIACA L.)
}

\author{
Kone Tchoa ${ }^{1}$, Soumahoro Brahima André ${ }^{2}$, Coulibaly Kpatolo Zana ${ }^{3}$, Traore Siaka ${ }^{4}$, \\ Kone Daouda ${ }^{5}$, Kone Mongomaké ${ }^{* 6}$ \\ 1,2,3,6 UFR Sciences de la Nature, Pôle de Recherche Productions Végétales, Université Nangui \\ Abrogoua, 02 BP 801 Abidjan 02, Côte d'Ivoire. \\ ${ }^{4}$ Station de Recherche de Bimbresso, Centre National de Recherche Agronomique (CNRA), 01 \\ BP 1536 Abidjan 01, Côte d'Ivoire. \\ ${ }^{5}$ UFR Biosciences, Université Felix Houphouët Boigny de Cocody, 22 BP 582 Abidjan 22, Côte \\ d'Ivoire.
}

\section{ABSTRACT}

Plantain (Musa paradisiaca) serves as a major staple food. However, its production is seasonal and this situation led to a shortage of more than five months (June to October). The extension of cultivable areas and the use of high yielding improved varieties are severely limited by the low availability of planting materials free of diseases and parasites. The purpose of this study is to establish optimal conditions for the mass production of clean planting materials. Freshly harvested suckers from plantain namely "Corne 1', “Orishele', "French 2', and 'Red Ebanga"' and suckers dried and stored for one month were trimmed and peeled so as to have four weight ranges. The prepared suckers were planted in propagator filled with different substrates. The results revealed that whatever the culture substrate used, the shortest time to induce shoots and the higher number of shoots were observed with dehydrated and nondehydrated suckers larger than 750g. Non-dehydrated Suckers with this weight expressed the longer lifetime (124-140 days). Among the substrates tested, shoots induction was faster with non-dehydrated suckers on fiber coco (12 days) and with dehydrated suckers on mix sawdust (15 days).

Keywords:

Plantain; suckers; buds; in vivo; plant propagation; dehydration.

Cite This Article: Kone Tchoa, Soumahoro Brahima André, Coulibaly Kpatolo Zana, Traore Siaka, Kone Daouda, Kone Mongomaké, "EFFECTS OF SUBSTRATES, WEIGHT AND PHYSIOLOGICAL STAGE OF SUCKERS ON MASSIVE PROPAGATION OF PLANTAIN (MUSA PARADISIACA L.)" International Journal of Research - Granthaalayah, Vol. 4, No. 1 (2016): 1-13. 


\section{INTRODUCTION}

Bananas and plantains (Musa spp. L.) are important staple foods for nearly 400 million people in many developing countries, especially in Africa. Total global production ranks fourth after maize, rice and wheat (Arias et al., 2003 ; Lassois et al., 2009). The world production of plantain in 2012 was estimated at over 37 million tons (FAOSTAT, 2013). With a production of 1.577 million tons per year, Côte d'Ivoire is the third plantain provider in West Africa (Lescot, 2006). Plantain is ranked the third food crops in Ivory Coast after yam and cassava (ANADER, 2009). The plant is grown throughout the tropics and plays an important role in the economies of many developing countries (Reyes-Borja et al., 2007). Thus, marketing on the local market is a source of employment and income for rural people.

Despite this importance, plantain production remains insufficient because of a strong domestic demand and the developing of sub-regional and international markets (Kouassi, 2004a). The plantain production is seasonal and this situation also leads to a shortage of more than five months (June to October). In order to ensure regular supply of consumer markets, production of plantain should be increased independently of seasons.

However, seasonality of production and the use of marginal and sensitive varieties to pests and diseases are major constraints to the regular market supply.

Moreover, a common limiting factor to large-scale production of bananas and plantains and or expansion of existing plantation is the difficulty in obtaining planting material (Baiyeri and Ajayi, 2000), due to poor suckering ability (Robinson, 1996). It is difficult to obtain a sufficient number of suckers in banana plantation because of the low natural rate suckering of plants and the poor quality of suckers which are often parasitized by nematodes and weevils.

To overcome these problems and increase the production of planting materials, several techniques are being developed by Agricultural Research Systems. Among them, micropropagation (plant tissue culture) allows more rapid production of planting materials which are healthy, vigorous and free from pests and diseases (Swennen, 1990) but require a more sophisticated technique, skill and care to handle (Vuylsteke and Talengera, 1998). Tissue culture as a method of generating planting materials is still poorly developed in Cote d'Ivoire and so, grossly unavailable to the subsistence farmers who are the major stakeholders in the production of bananas and plantain. The in vitro plant is not an option for traditional producers so there is a need for cheap and simple techniques (Lopez, 1994). A few in vivo nursery propagation techniques have increased the banana multiplication rate in field. This suckers rate varying initially from 1 to 5 per plant in peasant culture conditions, has reached an average number of 8 to 11 suckers per explant after application of these methods (Kwa 1998, Koné et al., 2011a, Koné, 2013). Although accessible to farmers, many of these in vivo methods present the risk of multiplying contaminated materials by nematodes or weevil. The technique of "plants issus de bourgeons secondaires" (PIBS) allows the activation of latent buds and the quick production of large quantities of healthy plantation materials (20-90) in soil-less culture conditions and adjustable for planting periods (Kwa, 2003 ; Koné, 2013; Dzomeku et al., 2014). The method generates plantlets from sucker utilizing sawdust as plantlet initiation medium. However, responses to the plantlet initiation on different substrates with suckers of different size and 
physiological stage have not yet been established. Therefore, the aim of this study was to compare white sawdust, red sawdust, mixed sawdust, rice hull and coconut fiber as initiation substrates, and three weight ranges and two physiological states (dehydrated and nondehydrated) of suckers as explants.

\section{MATERIALS AND METHODS}

\subsection{PLANT MATERIAL}

The plant material is composed with suckers of four plantain cultivars namely "Corne 1", "Orishele", "'French 2"' and "Red Ebanga'. These suckers are grown in experimental plot of University Nangui Abrogoua (Abidjan, South of Côte d'Ivoire).

\subsection{METHODS}

\section{CHEMICAL ANALYSIS OF SUBSTRATES}

The production of banana planting materiel has been recorded on five different types of substrates previously used by Kwa (2003) and Koné (2013). The planting substrates referred as red sawdust, white sawdust, mixed sawdust, coco fiber (supplied by SIGMA; Société Ivoirienne de Gestion des Matières Agronomiques) and rice hull have been submitted to a chemical analysis. Various methods were adopted to perform the substrates analysis. Briefly, phosphorus (P) content of the planting substrates was estimated according to Tausky and Shorr (1953) method, using the vanadate molybdate reagent. The rate of Nitrogen $(\mathrm{N})$ was determined by Kjeldahl method (Goyal et al., 2005). The level of organic carbon (CO) was measured following the method of M'Sadak (2012). The concentration of mineral elements ( $\mathrm{K}, \mathrm{Ca}, \mathrm{Na}, \mathrm{Mg}$ ) were estimated by flame photometry according to the AOAC rules Cunniff (1995).

\section{EXPLANTS PREPARATION}

Main steps describing the preparation of explants used as seeding in the propagators are illustrated by fig. 1. Suckers measuring 15 to $50 \mathrm{~cm}$ in height (above ground level) were collected and pared to remove all roots and pseudo-stem remains, followed by a thorough wash to remove plant and soil debris. The outer leaf sheaths were removed, one by one, $2 \mathrm{~mm}$ above the corm and from the leaf base with a sharp knife. The prepared material was then surfacesterilized for $15 \mathrm{~min}$ in a mixture of Furadan 5G (5 g/ 1) and Mancozeb $880 \mathrm{~W}$ (15 g / 1) and allowed to air-dry and cured for one to two days. Once the drying period is completed, a sharp knife is used to trim the surface of the explant until only 2-3 $\mathrm{mm}$ of the pseudostem remains. A right angle cross cut is made in the center of the explant. 

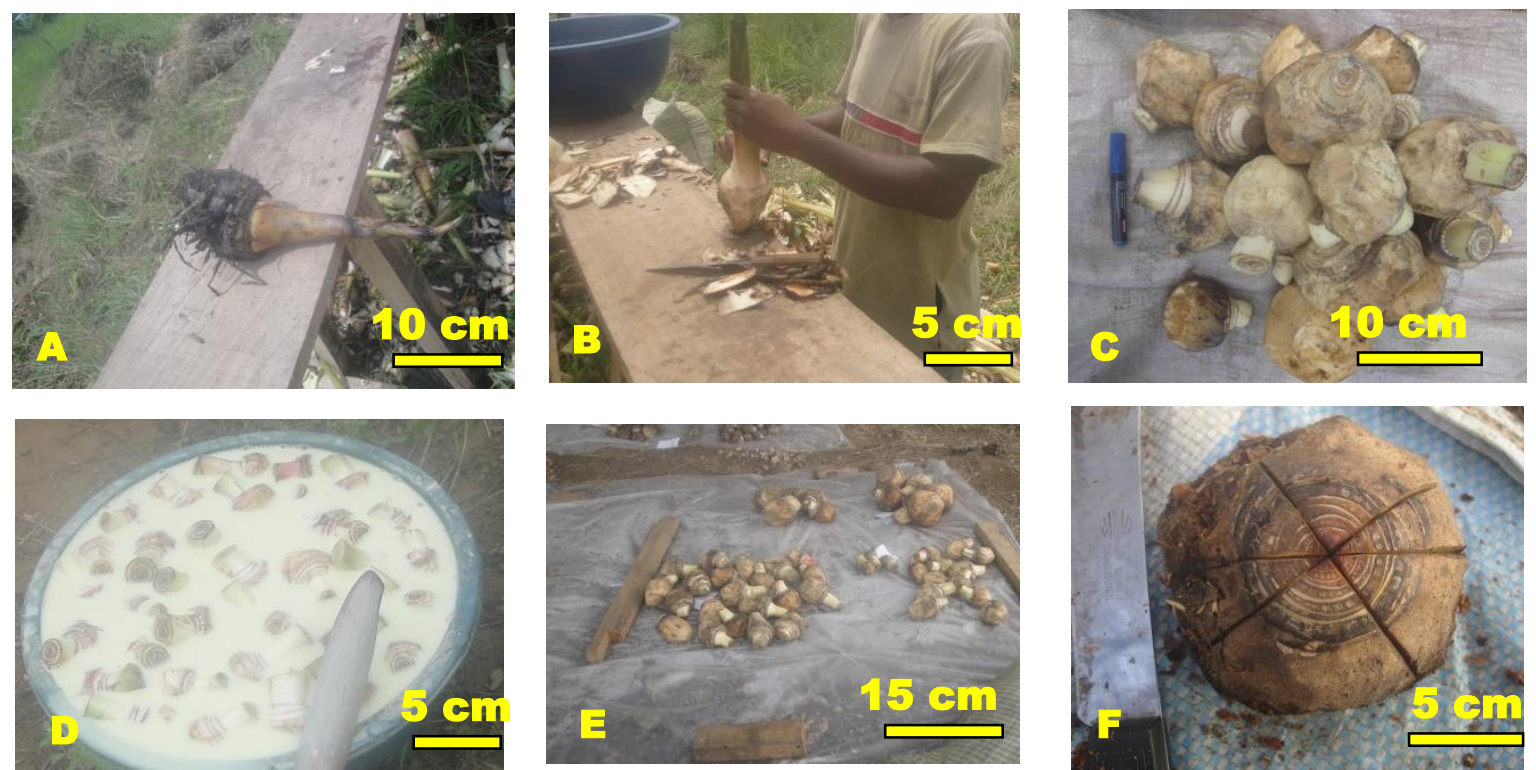

Figure 1: Different steps of the suckers' preparation before planting

A: Harvest suckers from plantain collection; B-C: Cleaning and paring of suckers; D: antifungal and insecticide treatment of suckers; E: Air-drying of suckers grouped by size; F: Double cross section on suckers ready to be

transferred in propagator.

BUDS INDUCTION FROM DIFFERENT WEIGHTS OF DEHYDRATED AND NONDEHYDRATED SUCKERS IN PROPAGATORS FILLED WITH DIFFERENT TYPES OF SUBSTRATES

The prepared suckers used as explants in propagators were grouped in four classes of weight (W): (1) $\mathrm{W}<250 \mathrm{~g}$; (2) $250 \mathrm{~g}<\mathrm{W}<500 \mathrm{~g}$; (3) $500 \mathrm{~g}<\mathrm{W}<750 \mathrm{~g}$ and $\mathrm{W}>750 \mathrm{~g}$. Half of these different suckers was air-dried for one month. The so prepared suckers were planted in propagators filled respectively with substrates consisting in red sawdust (S1), white sawdust (S2), mixed sawdust (S3), rice hull (S4) and coco fiber (S5). The suckers were planted at $30 \mathrm{~cm}$ intervals in the propagator with the crosscut facing up. The explants were covered fully with a 2 to $3 \mathrm{~cm}$ layer of substrate. The substrates were well watered immediately after the planting of suckers. Watering the substrates was renewed every 2 or 3 weeks when necessary.

\section{REACTIVATION OF EXPLANTS IN PROPAGATORS}

The reactivation is a means of increasing the number of plantlets per explant. Two to three weeks after planting, explants induced multiple buds which were developed in shoots. When the shoots reached thumb size, they are manipulated (scarified) to obtain secondary plantlets.

The shoots were then excised from the explant $2 \mathrm{~mm}$ above the node, and a new right angled crosscut in the pseudostem was made. After another three weeks, each of these shoots will give rise to multiple shoots again.

\section{ROOTING AND ACCLIMATIZATION OF PLANTLETS}

The emerged secondary shoots with two to three small leaves were excised from suckers. Those that have roots go straight into the potting mixture, using one plant per bag or cup. Those without 
roots were replanted in sawdust for a few days prior to their transfer to the potting mixture. Plantlets with roots were transferred to weaning facilities for acclimatization. Acclimatization was accomplished under shades for proper lighting and management. The Plantlets were watered four times a week. After three to six weeks in the weaning facility, the survived plants are ready for the field.

\section{DATA COLLECTION AND ANALYSIS}

In the propagators, ten suckers used per treatment, were arranged following a completely randomized design and three independent replicates per treatment were performed. The lag time for the buds induction, the average number of buds per explants and the explants lifetime were evaluated. Data collected were subjected to analysis of variance (ANOVA) to test for the significance of treatment effects using Statistica 7.1

When a difference was observed, the multiple range test of Newman-Keuls at $5 \%$ threshold was adopted to separate averages.

\section{RESULTS}

\section{CHEMICAL ANALYSIS OF GROWING SUBSTRATES}

The physicochemical characteristics of the culture substrates used in this study are shown in table 1.The results indicated that rice hull substrate exhibited higher levels of nitrogen $(\mathrm{N})$ $(0.887 \%)$, total Phosphor $(\mathrm{P})(1.674 \%)$, potassium $(\mathrm{K})(1.486 \mathrm{meq} / 100 \mathrm{~g})$ and Magnesium $(\mathrm{Mg})$ $(0.78 \mathrm{meq} / 100 \mathrm{~g})$. With the substrate coconut fiber, the contents in $\mathrm{N}(0.56 \%)$, total $\mathrm{P}(0.226$ meq / 100g), K (0.627 meq / 100g) and Mg (0.227 meq / 100g) were lower than those of other substrates.

The highest values of $\mathrm{pH}$ were recorded with the substrates red sawdust (7.64) and rice hull (7.28). These substrates tend to have alkaline $\mathrm{pH}$. The lowest $\mathrm{pH}$ was observed with white sawdust (6.01) and is closer to acid solution.

\section{AVERAGE TIME REQUIRED FOR THE INDUCTION OF BUDS}

The dehydrated and non-dehydrated suckers varying in size were used to produce buds on various types of substrates. The average time to induce buds in these different conditions was estimated and recorded in table 2. Whatever the physiological state of the suckers, the induction of buds on all the substrates was observed more rapidly when the size was superior to $750 \mathrm{~g}$. Longer latency times were expressed with the size of explants less than $250 \mathrm{~g}$. Compared to nondehydrated suckers, the average time to induce buds was shorter with dehydrated suckers. 
Table 1: Physicochemical characteristics of substrates in the propagators

\begin{tabular}{|c|c|c|c|c|}
\hline & $\begin{array}{l}\text { Coconut fiber } \\
\text { (Cf) }\end{array}$ & Rice hull (Rh) & Red sawdust (Rs) & White sawdust (Ws) \\
\hline $\mathbf{N}(\%)$ & 0.56 & 0.887 & 0.607 & 0.747 \\
\hline C organic (\%) & 55.92 & 53.44 & 55.09 & 57.25 \\
\hline$P$ total $(\%)$ & 0.226 & 1.674 & 0.94 & 1.167 \\
\hline K (méq/ 100g) & 0.627 & 1.486 & 0.883 & 1.16 \\
\hline Ca (méq/ 100g & 1.40 & 0.055 & 0.173 & 0.16 \\
\hline Mg (méq/ 100g) & 0.227 & 0.78 & 0.7 & 0.737 \\
\hline Na (méq/ 100g) & 0.034 & 0.0050 & 0.03 & 0.02 \\
\hline CEC (méq/ 100g) & 0.627 & 1.493 & 0.883 & 1.16 \\
\hline pH & 6.80 & 7.28 & 7.64 & 6.01 \\
\hline
\end{tabular}

With the non-dehydrated suckers, the substrate consisting in mixed sawdust allowed a quick induction of buds (15 days) while the shortest time to induce buds from dehydrated suckers was obtained on the substrate referred as coconut fiber (12 days).

\section{AVERAGE TIME REQUIRED FOR THE INDUCTION OF BUDS}

The dehydrated and non-dehydrated suckers varying in size were used to produce buds on various types of substrates. The average time to induce buds in these different conditions was estimated and recorded in table 2. Whatever the physiological state of the suckers, the induction of buds on all the substrates was observed more rapidly when the size was superior to $750 \mathrm{~g}$. Longer latency times were expressed with the size of explants less than $250 \mathrm{~g}$. Compared to nondehydrated suckers, the average time to induce buds was shorter with dehydrated suckers. With the non-dehydrated suckers, the substrate consisting in mixed sawdust allowed a quick induction of buds (15 days) while the shortest time to induce buds from dehydrated suckers was obtained on the substrate referred as coconut fiber (12 days).

Table 2: Average time (days) necessary for buds induction from dehydrated and non-dehydrated suckers of different sizes on various types of substrates

\begin{tabular}{|c|c|c|c|c|c|c|}
\hline \multirow{2}{*}{ Types of suckers } & \multicolumn{3}{|c|}{ Substrates } & \multirow[b]{2}{*}{ White sawdust } & \multirow[b]{2}{*}{ Mixed sawdust } & \multirow[b]{2}{*}{ Coconut fiber } \\
\hline & Suckers weight & Rice hull & Red sawdust & & & \\
\hline \multirow{4}{*}{ Non dehydrated } & $>750 \mathrm{~g}$ & $20.67 \pm 6.43 \mathbf{e}$ & $17.00 \pm 2.78 \mathbf{e}$ & $16.25 \pm 1.50 \mathrm{~g}$ & $15.00 \pm 1.45 \mathbf{f}$ & $21.00 \pm 3.56 \mathbf{e}$ \\
\hline & $500 \mathrm{~g}-750 \mathrm{~g}$ & $33.21 \pm 10.47 \mathbf{b}$ & $26.00 \pm 2.12 \mathrm{c}$ & $19.43 \pm 6.60 \mathbf{f}$ & $18.00 \pm 3.17 \mathrm{e}$ & $28.67 \pm 2.31 \mathrm{c}$ \\
\hline & $250 \mathrm{~g}-500 \mathrm{~g}$ & $34.67 \pm 5.74 \mathbf{b}$ & $33.80 \pm 9.58 \mathbf{b}$ & $26.65 \pm 12.69 \mathrm{c}$ & $30.00 \pm 4.23 \mathbf{b}$ & $29.00 \pm 5.13 \mathbf{b}$ \\
\hline & $<250 \mathrm{~g}$ & $39.71 \pm 7.87 \mathbf{a}$ & $36.00 \pm 12.12 \mathbf{a}$ & $24.00 \pm 8.98 \mathbf{d}$ & $37.00 \pm 4.71 \mathbf{a}$ & $32.00 \pm 13.86 \mathbf{a}$ \\
\hline Mean & & $32.07 \pm 7.63 * * * *$ & $28.2 \pm 6.65 * * *$ & $21.58 \pm 9.94^{*}$ & $25.00 \pm 3.39 * *$ & $27.67 \pm 11.22 * * * *$ \\
\hline \multirow{4}{*}{ Dehydrated } & $>750 \mathrm{~g}$ & $18.00 \pm 2.06 \mathbf{f}$ & $17.00 \pm 3.90 \mathbf{e}$ & $18.00 \pm 2.56 \mathbf{f}$ & $16.25 \pm 1.50 \mathrm{~g}$ & $11.80 \pm 1.45 \mathbf{h}$ \\
\hline & $500 \mathrm{~g}-750 \mathrm{~g}$ & $23.60 \pm 7.23 \mathbf{d}$ & $22.00 \pm 8.49 \mathbf{d}$ & $22.56 \pm 5.89 \mathrm{e}$ & $19.43 \pm 6.60 \mathbf{e}$ & $15.00 \pm 2.45 \mathrm{~g}$ \\
\hline & $250 \mathrm{~g}-500 \mathrm{~g}$ & $28.19 \pm 10.67 \mathbf{c}$ & $22.44 \pm 3.50 \mathbf{d}$ & $28.50 \pm 7.77 \mathbf{b}$ & $26.65 \pm 8.69 \mathbf{c}$ & $19.00 \pm 2.89 \mathbf{f}$ \\
\hline & $<250 \mathrm{~g}$ & $28.50 \pm 7.77 \mathbf{c}$ & $35.21 \pm 11.14 \mathbf{a}$ & $32.07 \pm 8.17 \mathbf{a}$ & $24.00 \pm 8.98 \mathbf{d}$ & $23.00 \pm 5.66 \mathbf{d}$ \\
\hline Mean & & $24.57 \pm 6.93 * * *$ & $24.16 \pm 6.76 * * *$ & $25.28 \pm 6.10 * * *$ & $21.58 \pm 6.44 * *$ & $17.20 \pm 5.61 *$ \\
\hline Means of means & & $28.32 \pm 7.28 * * * *$ & $26.18 \pm 6.70 * * *$ & $23.43 \pm 6.77 * *$ & $23.29 \pm 4.92 * *$ & $22.43 \pm 4.66 *$ \\
\hline
\end{tabular}


Within the same column and the same line, mean values followed by the same letter are not significantly different at $\alpha=5 \%$ according to Newman-Keuls test; (Mean \pm SD)

Within the same line, mean values followed by the same asterisk $(*)$ number are not significantly different at $\alpha=5 \%$ according to Newman-Keuls test; (Mean \pm SD)

Table 3: Average number of buds induced per dehydrated and non-dehydrated suckers of different sizes on various types of substrates

\begin{tabular}{|c|c|c|c|c|c|c|}
\hline \multirow{2}{*}{ Types of suckers } & \multicolumn{3}{|c|}{ Substrates } & \multirow[b]{2}{*}{ White sawdust } & \multirow[b]{2}{*}{ Mixed Sawdust } & \multirow[b]{2}{*}{ Coconut Fiber } \\
\hline & Suckers weight & Rice hull & Red sawdust & & & \\
\hline \multirow{4}{*}{ Non dehydrated } & $>750 \mathrm{~g}$ & $56.60 \pm 9.78 \mathbf{a}$ & $75.09 \pm 5.46 \mathbf{a}$ & $71.86 \pm 6.32 \mathbf{a}$ & $68.43 \pm 15.91 \mathbf{a}$ & $84.12 \pm 4.56 \mathbf{a}$ \\
\hline & $500 \mathrm{~g}-750 \mathrm{~g}$ & $41.82 \pm 5.10 \mathrm{c}$ & $38.62 \pm 3.25 \mathrm{c}$ & $38.25 \pm 3.87 \mathrm{c}$ & $37.35 \pm 3.41 \mathbf{b}$ & $37.40 \pm 6.11 \mathbf{b}$ \\
\hline & $250 \mathrm{~g}-500 \mathrm{~g}$ & $21.77 \pm 4.99 \mathbf{d}$ & $22.62 \pm 3.12 \mathrm{~d}$ & $28.54 \pm 4.35 \mathbf{d}$ & $19.31 \pm 5.30 \mathbf{e}$ & $24.05 \pm 4.45 \mathrm{c}$ \\
\hline & $<250 \mathrm{~g}$ & $10.478 \pm 7.57 \mathbf{e}$ & $7.61 \pm 1.57 \mathbf{f}$ & $8.51 \pm 3.26 \mathbf{f}$ & $11.70 \pm 3.20 \mathbf{g}$ & $11.35 \pm 1.68 \mathbf{e}$ \\
\hline Mean & & $32.67 \pm 6.86^{* * * *}$ & $35.99 \pm 3.35 * *$ & $36.79 \pm 4.45 * *$ & $34.20 \pm 6.96 * *$ & $39.23 \pm 4.20 *$ \\
\hline \multirow{4}{*}{ Dehydrated } & $>750 \mathrm{~g}$ & $53.69 \pm 10.93 \mathbf{a b}$ & $67.00 \pm 14.19 \mathbf{a}$ & $62.57 \pm 7.49 \mathbf{a}$ & $73.68 \pm 13.13 \mathbf{a}$ & $74.04 \pm 6.32 \mathbf{a}$ \\
\hline & 500g-750g & $51.532 \pm 9.37 \mathbf{b}$ & $40.04 \pm 8.36 \mathbf{b}$ & $42.63 \pm 13.98 \mathbf{b}$ & $44.98 \pm 7.12 \mathbf{b}$ & $54.95 \pm 7.03 \mathbf{b}$ \\
\hline & $250 \mathrm{~g}-500 \mathrm{~g}$ & $20.71 \pm 6.17 \mathbf{d}$ & $38.16 \pm 11.84 \mathbf{c}$ & $33.52 \pm 10.21 \mathrm{c}$ & $28.89 \pm 9.33 \mathbf{d}$ & $29.10 \pm 5.25 \mathbf{c}$ \\
\hline & $<250 \mathrm{~g}$ & $12.766 \pm 4.95 \mathbf{e}$ & $18.02 \pm 9.53 \mathbf{e}$ & $18.67 \pm 9.15 \mathbf{e}$ & $15.18 \pm 9.04 \mathbf{f}$ & $15.55 \pm 9.57 \mathrm{~d}$ \\
\hline Mean & & $34.67 \pm 7.86^{* * * *}$ & $40.81 \pm 10.98 * *$ & $39.35 \pm 10.21 * *$ & $40.68 \pm 9.66^{* *}$ & $43.41 \pm 7.04 *$ \\
\hline
\end{tabular}

Within the same column and the same line, mean values followed by the same letter are not significantly different at $\alpha=5 \%$ according to Newman-Keuls test; (Mean \pm SD)

Within the same line, mean values followed by the same asterisk (*) number are not significantly different at $\alpha=5 \%$ according to Newman-Keuls test; (Mean \pm SD)

\section{POTENTIAL PRODUCTION OF BUDS DERIVED FROM SUCKERS PLANTED IN VARIOUS SUBSTRATES}

In table 3, the average number of buds induced by dehydrated and non-dehydrated suckers of different sizes on various types of substrates was indicated. On all substrates used in propagators, the average number of buds induced by the dehydrated and non- dehydrated suckers varied significantly depending on their weight. The suckers with weight $>750 \mathrm{~g}$ produced the largest number of buds. With the suckers of this size, no significant difference in the average number of induced buds was observed between the tested substrates.

\section{AVERAGE LIFE OF SUCKERS FOR THE PRODUCTION OF BUDS}

The average lifespan of suckers in production on the various substrates significantly decreased when low weight explants were used (Table 4). Whatever the substrate used, the average production time of buds by dehydrated suckers is statistically lower than that of non- dehydrated suckers. Compared to the others substrates, the average production time of buds was shorter in propagators filled with coconut fiber. 


\section{PRODUCTION OF BUDS BY DIFFERENT CULTIVARS OF BANANA PLANTAIN}

The average number of buds induced per explants in various cultivars of plantain was represented in table 5. The analysis of these results shown that, independently to suckers size, plantain cultivars namely, Red Ebanga, Corn 1, Orishele and French 2 expressed the higher number of buds per explants when propagators were filled with coconut fiber as substrate. The average number of buds per explants varied from 42 to 48 and no variability was observed among the cultivars. Moreover, explants with size superior than $750 \mathrm{~g}$ allowed all cultivars to produce on coconut fiber an average number of buds per explants varying between 80 and 85 . However, in farmers' conditions where financing is quite limited, the use of readily available substrates or very low cost production equipment remains the most suitable strategy for the production of planting material. Thereby, for a significant production of planting material, the suckers of the variety "Red Ebanga" have to be planted in the propagators filled with mixed sawdust. The Red sawdust substrate is more suitable for the variety 'Orishele', All the types of sawdust are convenient as substrates for the variety 'Corn'. Concerning the variety 'French 2 ', the best substrates are Rice hull, Red and White sawdust.

Table 4: Average life (days) of dehydrated and non-dehydrated suckers of different sizes for the production of buds on various types of substrates

\begin{tabular}{|c|c|c|c|c|c|c|}
\hline \multirow{2}{*}{ Types of suckers } & \multicolumn{6}{|c|}{ Substrates } \\
\hline & Suckers weight & Rice hull & Red sawdust & White sawdust & Mixed Sawdust & Coconut Fiber \\
\hline \multirow{3}{*}{ Non dehydrated } & $>750 \mathrm{~g}$ & $139.67 \pm 7.40 \mathbf{a}$ & $137.00 \pm 10.78 \mathbf{a}$ & $146.25 \pm 1.50 \mathbf{a}$ & $135.00 \pm 1.45 \mathbf{a}$ & $124.00 \pm 9.56 \mathbf{a}$ \\
\hline & $500 \mathrm{~g}-750 \mathrm{~g}$ & $123.21 \pm 15.17 \mathbf{b}$ & $126.00 \pm 9.72 \mathbf{c}$ & $119.43 \pm 8.00 \mathbf{b}$ & $118.00 \pm 2.14 \mathbf{b}$ & $116.67 \pm 7.35 \mathbf{b}$ \\
\hline & $<250 \mathrm{~g}$ & $109.71 \pm 7.56 \mathbf{e}$ & $116.00 \pm 12.12 \mathrm{~d}$ & $32.00 \pm 4.58 \mathrm{e}$ & $37.00 \pm 4.71 \mathbf{e}$ & $32.00 \pm 13.86 \mathbf{g}$ \\
\hline \multicolumn{2}{|c|}{ Mean } & $121.82 \pm 8.97 *$ & $128.20 \pm 10.82 *$ & $103.58 \pm 9.44 * *$ & $95.00 \pm 3.08 * * *$ & $91.64 \pm 10.47 * * *$ \\
\hline \multirow{2}{*}{ Dehydrated } & $>750 \mathrm{~g}$ & $119.00 \pm 9.60 \mathrm{c}$ & $107.00 \pm 5.00 \mathbf{e}$ & $118.00 \pm 2.56 \mathbf{b}$ & $116.25 \pm 5.50 \mathrm{~b}$ & $98.80 \pm 9.15 \mathbf{d}$ \\
\hline & $500 \mathrm{~g}-750 \mathrm{~g}$ & $103.60 \pm 7.23 \mathbf{f}$ & $92.00 \pm 5.49 \mathbf{f}$ & $112.56 \pm 5.89 \mathrm{c}$ & $95.43 \pm 3.60 \mathrm{c}$ & $65.00 \pm 6.75 \mathbf{e}$ \\
\hline \multicolumn{2}{|c|}{ Mean } & $84.75 \pm 7.01 *$ & $73.42 \pm 5.61 * *$ & $85.41 \pm 6.30^{*}$ & $81.05 \pm 6.50 *$ & $61.7 \pm 14.66^{* * * *}$ \\
\hline \multicolumn{2}{|l|}{ Mean of means } & $90.78 \pm 7.99 *$ & $100.81 \pm 8.08 *$ & $94.49 \pm 7.87 *$ & $88.02 \pm 5.26 *$ & $76.67 \pm 8.82 *$ \\
\hline
\end{tabular}

Within the same column and the same line, mean values followed by the same letter are not significantly different at $\alpha=5 \%$ according to Newman-Keuls test; (Mean \pm SD)

Within the same line, mean values followed by the same asterisk (*) number are not significantly different at $\alpha=5 \%$ according to Newman-Keuls test; (Mean \pm SD) 
Table 5: Average number of buds produced on five different substrates depending on weight of four plantain cultivars

\begin{tabular}{|c|c|c|c|c|c|c|}
\hline Cultivars & Weight & Rice hull & Red sawdust & White sawdust & Mixed sawdust & Coconut fiber \\
\hline \multirow{4}{*}{ "'Red Ebenga'” } & $>750 \mathrm{~g}$ & $41.79 \pm 9.45 \mathrm{c}$ & $64.52 \pm 12.18 \mathbf{b}$ & $69.51 \pm 16.80 \mathbf{b}$ & $72.23 \pm 14.67 \mathbf{a}$ & $84.01 \pm 14.16 \mathbf{a}$ \\
\hline & $500 \mathrm{~g}-750 \mathrm{~g}$ & $28.68 \pm 6.64 \mathbf{d}$ & $31.02 \pm 4.15 \mathbf{e}$ & $28.6 \pm 2.33 \mathbf{d}$ & $35.48 \pm 3.12 \mathbf{d}$ & $46.14 \pm 8.98 \mathbf{c}$ \\
\hline & $250 g-500 g$ & $25.53 \pm 7.29 \mathbf{e}$ & $32.56 \pm 6.31 \mathrm{e}$ & $27.73 \pm 4.87 \mathbf{d}$ & $22.48 \pm 4.06 \mathbf{e}$ & $31.55 \pm 3.27 \mathbf{d}$ \\
\hline & $<250 \mathrm{~g}$ & $8.25 \pm 1.50 \mathbf{h}$ & $16.29 \pm 4.99 \mathbf{h}$ & $20.47 \pm 3.94 \mathbf{e}$ & $13.65 \pm 2.07 \mathbf{g}$ & $14.44 \pm 5.67 \mathbf{f}$ \\
\hline \multicolumn{2}{|l|}{ Mean } & $26.06 \pm 6.22 * * *$ & $36.10 \pm 6.91 * *$ & $36.58 \pm 6.99 * *$ & $35.96 \pm 5.98 * *$ & $44.70 \pm 5.97 *$ \\
\hline \multirow{4}{*}{ "Orishele" } & $>750 \mathrm{~g}$ & $42.341 \pm 4.55 \mathrm{c}$ & $73.15 \pm 14.11 \mathbf{a}$ & $69.12 \pm 16.11 \mathrm{~b}$ & $50.52 \pm 19.83 \mathbf{c}$ & $82.33 \pm 23.42 \mathbf{a}$ \\
\hline & $500 \mathrm{~g}-750 \mathrm{~g}$ & $28.08 \pm 5.72 \mathbf{d}$ & $50.59 \pm 8.81 \mathbf{c}$ & $33.37 \pm 7.46 \mathbf{c d}$ & $27.87 \pm 4.58 \mathrm{de}$ & $49.38 \pm 4.07 \mathbf{c}$ \\
\hline & $250 g-500 g$ & $19.18 \pm 4.89 \mathbf{g}$ & $18.67 \pm 3.54 \mathbf{g}$ & $19.08 \pm 2.58 \mathbf{e}$ & $20.12 \pm 3.51 \mathbf{e}$ & $24.61 \pm 11.81 \mathrm{e}$ \\
\hline & $<250 \mathrm{~g}$ & $6.35 \pm 1.08 \mathbf{h}$ & $12.17 \pm 3.86 \mathbf{i}$ & $12.06 \pm 2.35 \mathbf{f}$ & $8.45 \pm 2.79 \mathbf{i}$ & $12.08 \pm 4.66 \mathbf{f}$ \\
\hline \multicolumn{2}{|l|}{ Mean } & $23.99 \pm 4.06 * * *$ & $38.65 \pm 7.58 *$ & $33.41 \pm 7.13 * *$ & $26.74 \pm 7.68 * * *$ & $42.10 \pm 10.99 *$ \\
\hline \multirow{4}{*}{ “'Corne 1', } & $>750 \mathrm{~g}$ & $56.60 \pm 13.78 \mathbf{b}$ & $75.10 \pm 10.46 \mathbf{a}$ & $71.88 \pm 16.32 \mathbf{a}$ & $68.43 \pm 14.92 \mathbf{a}$ & $84.12 \pm 24.56 \mathbf{a}$ \\
\hline & $500 \mathrm{~g}-750 \mathrm{~g}$ & $41.83 \pm 9.10 \mathbf{c}$ & $38.62 \pm 7.25$ de & $38.26 \pm 7.87 \mathbf{c}$ & $37.35 \pm 5.41 \mathbf{d}$ & $47.40 \pm 6.11 \mathrm{c}$ \\
\hline & $250 g-500 g$ & $21.76 \pm 2.99 \mathbf{f}$ & $22.62 \pm 3.12 \mathbf{f}$ & $28.53 \pm 4.35 \mathbf{d}$ & $19.30 \pm 5.30 \mathbf{e}$ & $34.05 \pm 4.45 \mathbf{d}$ \\
\hline & $<250 \mathrm{~g}$ & $8.06 \pm 1.57 \mathbf{h}$ & $7.60 \pm 1.57 \mathbf{j}$ & $8.53 \pm 3.26 \mathrm{fg}$ & $11.70 \pm 3.20 \mathbf{h}$ & $11.35 \pm 1.69 \mathbf{f}$ \\
\hline \multicolumn{2}{|l|}{ Mean } & $32.06 \pm 6.86^{* * * *}$ & $35.98 \pm 5.60 * *$ & $36.80 \pm 7.95 * *$ & $34.19 \pm 7.21 * * *$ & $44.23 \pm 9.20 *$ \\
\hline \multirow{4}{*}{ "French 2'” } & $>750 \mathrm{~g}$ & $77.53 \pm 13.64 \mathbf{a}$ & $72.50 \pm 17.30 \mathbf{a}$ & $74.02 \pm 15.83 \mathbf{a}$ & $60.94 \pm 4.76 \mathbf{b}$ & $80.60 \pm 17.40 \mathbf{a}$ \\
\hline & $500 \mathrm{~g}-750 \mathrm{~g}$ & $29.65 \pm 8.04 \mathbf{d}$ & $42.41 \pm 11.57 \mathbf{d}$ & $40.47 \pm 9.54 \mathbf{c}$ & $21.78 \pm 5.12 \mathbf{e}$ & $55.92 \pm 9.84 \mathbf{b}$ \\
\hline & $250 g-500 g$ & $18.36 \pm 4.12 \mathbf{g}$ & $19.60 \pm 5.17 \mathrm{~g}$ & $32.88 \pm 13.57 \mathrm{~cd}$ & $16.09 \pm 3.92 \mathbf{f}$ & $31.72 \pm 10.52 \mathrm{~d}$ \\
\hline & $<250 \mathrm{~g}$ & $8.41 \pm 1.36 \mathbf{h}$ & $8.45 \pm 2.00 \mathbf{j}$ & $9.46 \pm 1.90 \mathbf{f g}$ & $14.13 \pm 2.42 \mathbf{g}$ & $22.97 \pm 2.60 \mathbf{e}$ \\
\hline \multicolumn{2}{|l|}{ Mean } & $33.49 \pm 6.79 * *$ & $35.74 \pm 9.01 * *$ & $39.21 \pm 10.21 * *$ & $28.24 \pm 4.06 * * *$ & $47.80 \pm 10.09^{*}$ \\
\hline
\end{tabular}

Within the same column and the same line, mean values followed by the same letter are not significantly different at $\alpha=5 \%$ according to Newman-Keuls test; (Mean \pm SD)

Within the same line, mean values followed by the same asterisk (*) number are not significantly different at $\alpha=5 \%$ according to Newman-Keuls test; (Mean \pm SD)

\section{WEANING AND ACCLIMATIZATION OF PLANTLETS}

During the acclimatization phase of plants produced in propagators, the survival rate and the average time needed for the transfer of acclimated plants to the field were evaluated. The experimental values obtained were summarized in table 6.

Whatever the substrate used during the acclimatization stage, the survival rates obtained with the plantlets of plantain varieties varied between 79 and $100 \%$. No statistical difference was noticed among these values. Primary shoot formation to a acclimated plantlet ready to be transferring into field, between 64 to 100 days were needed independently to the varieties.

The fig. 2 illustrated the main steps going from proliferating explants in the propagator to the acclimated plantlets ready to be transferring to the field 
Table 6: Survival rate and average time necessary to transfer acclimated plants to the field

\begin{tabular}{|c|c|c|c|}
\hline Cultivars & Substrates & Survival rate $(\%)$ & $\begin{array}{l}\text { Average time for plantlets ready } \\
\text { for field planting (days) }\end{array}$ \\
\hline \multirow{5}{*}{ "Red Ebenga"' } & Rice hull & $79.72 \pm 1.09 \mathrm{a}$ & $86.56 \pm 11.31 \mathrm{a}$ \\
\hline & Red sawdust & $92.33 \pm 6.23 \mathrm{a}$ & $79.06 \pm 09.89 \mathrm{a}$ \\
\hline & White sawdust & $98.78 \pm 2.12 \mathrm{a}$ & $71.95 \pm 12.81 \mathrm{a}$ \\
\hline & Mixed sawdust & $100.00 \pm 0.00 \mathrm{a}$ & $82.52 \pm 12.64 \mathrm{a}$ \\
\hline & Coconut fiber & $100.00 \pm 0.00 \mathrm{a}$ & $64.39 \pm 16.30 \mathrm{a}$ \\
\hline \multirow{5}{*}{ "'Orishele" } & Rice hull & $100.00 \pm 0.00 \mathrm{a}$ & $100.80 \pm 19.07 \mathrm{a}$ \\
\hline & Red sawdust & $98.20 \pm 3.12 \mathrm{a}$ & $72.58 \pm 13.69 \mathrm{a}$ \\
\hline & White sawdust & $96.57 \pm 3.37 \mathrm{a}$ & $88.41 \pm 14.91 \mathrm{a}$ \\
\hline & Mixed sawdust & $96.56 \pm 5.95 a$ & $78.23 \pm 15.93 \mathrm{a}$ \\
\hline & Coconut fiber & $99.67 \pm 1.04 \mathrm{a}$ & $70.03 \pm 11.79 \mathrm{a}$ \\
\hline \multirow{5}{*}{ "Corne 1" } & Rice hull & $97.85 \pm 2.16 \mathrm{a}$ & $93.09 \pm 13.94 \mathrm{a}$ \\
\hline & Red sawdust & $96.62 \pm 5.85 \mathrm{a}$ & $75.72 \pm 10.29 \mathrm{a}$ \\
\hline & White sawdust & $82.74 \pm 5.68 \mathrm{a}$ & $85.16 \pm 13.22 \mathrm{a}$ \\
\hline & Mixed sawdust & $93.54 \pm 9.72 \mathrm{a}$ & $80.74 \pm 11.09 \mathrm{a}$ \\
\hline & Coconut fiber & $100.00 \pm 0.00 \mathrm{a}$ & $68.79 \pm 10.67 \mathrm{a}$ \\
\hline \multirow{5}{*}{ "French 2" } & Rice hull & $93.29 \pm 9.46 \mathrm{a}$ & $97.81 \pm 16.38 \mathrm{a}$ \\
\hline & Red sawdust & $90.21 \pm 10.60 \mathrm{a}$ & $83.73 \pm 09.39 \mathrm{a}$ \\
\hline & White sawdust & $86.82 \pm 6.33 \mathrm{a}$ & $95.39 \pm 15.99 \mathrm{a}$ \\
\hline & Mixed sawdust & $96.67 \pm 5.77 \mathrm{a}$ & $84.94 \pm 10.66 \mathrm{a}$ \\
\hline & Coconut fiber & $100.00 \pm 0.00 \mathrm{a}$ & $72.93 \pm 09.72 \mathrm{a}$ \\
\hline$P$ & & 0.069038207078 & 0.24307100983 \\
\hline
\end{tabular}

Within the same column, mean values followed by the same letter are not significantly different at $\alpha=5 \%$ according to Newman-Keuls test; (Mean $\pm \mathrm{SD}$ )
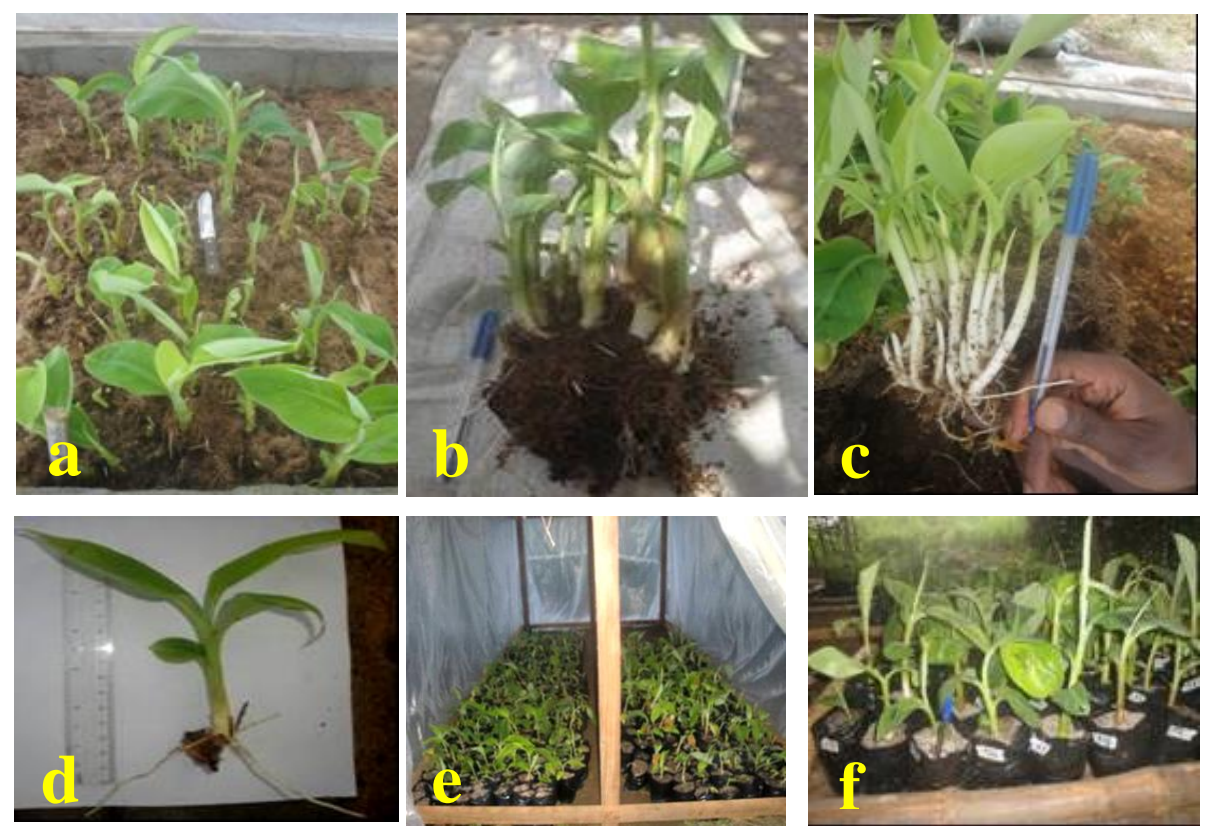

Figure 2: Production of the PIF plantlets and the procedure of weaning and hardening

(a) Explants proliferating in propagator; (b) primary shoots emerging from axillary buds on the corms; (c) Formation of multiple secondary shoots after reactivation of primary shoots; (d) rooted leafy shoots excised; (e) Plantlets being acclimatized; (f) Plantlets ready for field planting. 


\section{DISCUSSION}

The concentration of mineral compounds varied with the type of substrates used to fill the propagators. The nature of the substrates in terms of their principal components may explain the difference observed in their physicochemical properties. Apart the content in sodium, the coconut fiber substrate, compared to the others, exhibited a lower concentration in mineral elements. In fact, the development of the coconut tree on the sandy substrate with a weak amount of organic and inorganic elements resulted in a low accumulation of these elements in the fruits and then in the exocarp used to produce coconut fiber.

The results reported in this study indicated that the time necessary to observe the buds induction from suckers highly depends on their size and Physiological state. Explants with high size respond more rapidly to buds induction because of the importance of nutritive reserves of tissue and a lesser susceptibility to stress occurring during the process of sucker preparation before planting in propagator. In relation to the physiological state of explants, the time to induce buds seems substrate-specific. Therefore, non-dehydrated suckers performed the buds induction more rapidly when they were planted on white sawdust substrate. With the dehydrated suckers, the buds induction was firstly observed on the coconut fiber substrate.

Whatever the physiological state of the suckers, the highest average number of buds induced was obtained with the biggest explants. These types of suckers contain sufficient nutritive reserve and a great number of axillary buds which could be activated after having destroyed the apical meristem by double cross incision. Similar observations have already been reported (Koné et al., 2011b; Koné, 2013; Dzomeku et al., 2014). An important finding exhibited by the results is the possibility to air-dry the suckers for one month before using them as planting material in propagator. By the process of dehydration, suckers like the orthodox seeds enter into a dormancy phase which would inhibit buds sprouting. Therefore, dehydration allows a better management of the stock of planting material during renewing or extension of the cultivable areas with plantains. Moreover, in earlier studies, Boyé et al. (2008) reported that the conservation of suckers for one month did not alter the reactivity of meristematic tissue to induce buds as soon as the substrate will sufficiently be watered.

Concerning the average lifespan of suckers in production, our results revealed that the time was reduced when the explants used as planting material were either dried or small and the substrate in the propagator consisted of coconut fibers. The short production time has favored a limited number of cycles for induction of buds and in fact, a low total number of shoots produced by explants. Dehydration is a loss of water from the tissues which induces stress which strongly affects the integrity of tissues. These tissues, once reactivated by a new influx of water will tend to disintegrate more rapidly than the surrounding medium will be saturated with water. The lifespan of dehydrated explants was shortest, compared to the non-dehydrated suckers. The dehydrated explants have mobilized in a little time, all the nutritive reserves. Beyond this period, the explants quickly degenerate and all new productions of seedlings were prevented. These results are consistent with the observations made by Kwa (2003), which showed that beyond 2 to 3 months of culture, the basic explants start to degenerate and all new proliferations were hampered. When the explants have low weight, the nutrients reserves are quickly depleted and needs are provided by the contribution of the culture substrate. 
The results on the number of buds have shown that all plantain varieties have the potential to produce suckers in quantity under propagators conditions. However, this production is highly dependent on the size of suckers and especially the type of substrate used in propagators. In our experimental conditions, suckers with size superior to $750 \mathrm{~g}$ and coconut fiber substrate have yielded the best responses in terms of number of shoot buds developed in all varieties tested. The large suckers accumulate important quantities of nutrients mobilized for the induction of buds. Moreover, their volume allows the distribution of a greater number of latent buds that are activated after the stress suffered by the apical meristem. The best responses obtained with the coconut fiber substrate may be explained by a more rapid decomposition of this substrate compared to the others. This decomposition resulted in a better release of minerals in propagators and an easy uptake by the explants.

\section{CONCLUSION}

The present study revealed that the substrate of coconut fiber produced a greater number of buds whatever the cultivar. This substrate could then be recommended as a substrate of choice for a mass production of planting material in plantain.

The size of suckers used in propagators is of importance for the buds induction. Then, the suckers with high size, superior to $750 \mathrm{~g}$, performed well in buds production. When different types of sawdust substrates were used, variability was observed among the plantain varieties in terms of buds production efficiency. Nevertheless, it remains the most suitable substrate for mass propagation of planting material. Its availability and low cost make it the substrate of choice for the farmers with low incomes.

The study also showed the possibility to dehydrate the suckers for one month before using them as explants in propagator without any detrimental effect in the potential of buds production.

\section{ACKNOWLEDGEMENTS}

The project was supported by FIRCA (Fonds Interprofessionnel pour la Recherche et le Conseil Agricoles) via the West Africa Agricultural Productivity Program (WAAPP).

\section{REFERENCES}

[1] Arias, P., Dankers, C., Liu, P. and Pilkauskas, P., The world banana economy 19852002. Rome: Food and Agriculture Organization of the United Nations; 2003, 100 p.

[2] Lassois, L., Busogoro, J.-P. and Jijakli, H., La banane : de son origine à sa commercialisation. Biotechnology, Agronomy, Society and Environment, Vol. 13, No. 4, 2009, 575-586.

[3] FAOSTAT, http://faostat3.fao.org/faostat-gateway/go/to/browse/Q/QC/F 2013 (Consulted the 19 Août 2014)

[4] Lescot, T., Estimation de la production et du commerce bananier mondial. FruiTrop, Vol. 140, 2006, 6-9.

[5] ANADER, La production vivrière: un enjeu national. Bulletin de liaison de l'Agence Nationale de DEveloppement Rural. Côte d'Ivoire. Le Partenaire, No. 14: 2009, 12p. 
[6] Reyes-Borja, W.O., Sotomayor, I., Garzón, I., Vera, D., Cedeño, M., Castillo, B., Tanaka, A., Hase, Y., Sekozawa, Y., Sugaya, S. and Gemma, H., Alteration of resistance to black Sigatoka (Mycosphaerellafijiensis Morelet) in banana by in vitro irradiation using carbon ion-beam. Plant Biotechnology, Vol. 24, 2007, 349-353.

[7] Kouassi, K.S., Enquête sur les aspects socioculturel et ethnologique des bananiers plantain en Côte d'Ivoire. Projet de thèse. Document CNRA. 2004, 22p.

[8] Baiyeri, K.P. and Ajayi, A.R., Status and constraints of Musa spp. Production in a subhumid zone of Nigeria. Acta Horticulturae, Vol. 540, 2000, 73 - 77

[9] Robinson, J.C., Bananas and Plantains. CAB International, UK., 1996, 238.

[10] Swennen, R., Plantain cultivation under West African Conditions: A reference Manual. Int. Inst. Trop. Agric., Ibadan, Nigeria, 1990, 24

[11] Vuylsteke, D. and Talengera, D., Postflask management of micropropagated bananas and plantain plants. IITA, Ibadan Nigeria, 1998, 15.

[12] Lopez, F.G., Technique rapide de multiplication du bananier plantain en Colombie. InfoMusa, Vol. 3 No. 2, 1994, 7.

[13] Kwa, M., Production de rejets chez les bananiers en cultures intensives. Fruit, Vol. 53, No. 6, 1998, 365-374.

[14] Koné, T., Koné, M., Koné, D., Traoré, S. and Kouadio, Y.J., Multiplication rapide du bananier plantain (Musa spp., AAB) in situ : une alternative pour la production en masse de rejets. Agronomie Africaine, Vol. 23 No. 1, 2011a, 21-31.

[15] Koné, T., Optimisation de la production de matériel végétal sous forme de semences chez trois cultivars (Orishele, Corne 1 et French 2) de bananiers plantain [Musa spp., AAB (Musaceae)] cultivés en Côte d'Ivoire. Thèse de Doctorat Unique, Université Nangui Abrogoua, Abidjan, Côte d'Ivoire, 2013, 162p.

[16] Kwa M., Activation de bourgeons latents et utilisation de fragments de tige du bananier pour la propagation en masse de plants en conditions horticoles in vivo. Fruits, Vol 58, No 6, 2003, 315 -328.

[17] Dzomeku, B.M., Darkey, S. K., Wünsche, J.N., Bam, R.K., Response of selected local plantain cultivars to PIBS (plants issus de bourgeons secondaires) technique, J. Plant Develop. 21, 2014, 117-123

[18] Tausky, H.H. and Shorr E., A micro colorimetric method for determination of inorganic phosphrorus, J. Biol. Chem. Vol. 202, 1953, 675-685

[19] Goyal, S., Dhull, S.K., Kapoor, K.K., 2005 - Chemical and biological changes during composting of different organic wastes and assessment of compost maturity. Bioresource Technology, Vol. 96, 2005, 1584-1591

[20] M'Sadak, Y., Ben, M.A, Tayachi, L., Possibilités d'incorporation du méthacompost avicole dans la confection des substrats de culture à base de compost sylvicole en pépinière forestière, Nature \& Technologie, Vol. 6, 2012, 59-70

[21] Cunniff, P., Official Methods of Analysis of the Association of Official Analytical Chemistry (AOAC). 16th Edn., AOAC International, Washington, USA., 1995, 1141.

[22] Koné T., Koné M., Da Silva J.A.T., Koné D \& Kouadio Y.J., Effect of substrate type and bulb size on in vivo production of seedling in three cultivars of plantain (Musa spp.). The African Journal of Plant Science and Biotechnology, Vol 5 No 1, 2011b, 50-55.

[23] Boyé, M.A.D., Coulibaly, D.R., Turquin, L., Anno, A.P. and Zouzou, M., Caractérisation pathologique in vivo du stress hydrique sur les rejet-écailles de bananier plantain Musa $A A B$ cv Corne 1. Revue Ivoirienne de Sciences et Technologie, 11, 2008, 143-158. 